\title{
The Key Role of Peptidoglycan in the Opsonization of Staphylococcus Aureus
}

\author{
Phillip K. Peterson, Brian J. Wilkinson, Youngki Kim, David Schmeling, \\ Steven D. Douglas, and Paul G. Quie, the Departments of Medicine, Pediatrics, \\ and Microbiology, University of Minnesota School of Medicine, Minneapolis, \\ Minnesota 55455 \\ JAN VERHOEF, Laboratory for Microbiology, Utrecht, Netherlands
}

\begin{abstract}
A B S T R A C T In an effort to determine the staphylococcal cell surface component(s) of importance in opsonization, cell walls (peptidoglycan and teichoic acid) and peptidoglycan were isolated from Staphylococcus aureus strain $\mathrm{H}$ grown in $\left[{ }^{3} \mathrm{H}\right]$ glycine-containing broth. After incubation of the cell walls and peptidoglycan with various opsonic sources, uptake by human polymorphonuclear leukocytes was measured. The opsonic requirements for phagocytosis of cell walls and peptidoglycan were found to be similar to those of intact bacteria. Removal of teichoic acid from the cell wall did not affect opsonization. Likewise, a teichoic acid-deficient mutant strain of $S$. aureus $\mathrm{H}$ was opsonized in a manner similar to that of the parent strain. Immunoglobulin G functioned as the major heat-stable opsonic factor and both the classical and alternative pathways participated in opsonization. Kinetic studies revealed that opsonization of peptidoglycan, as well as C3-C9 consumption by peptidoglycan, proceeded at a slower rate via the alternative pathway (C2-deficient serum) than when the classical pathway was present (normal serum). The ability of peptidoglycan to activate C3-C9 was significantly reduced when normal and $\mathrm{C} 2$-deficient sera were preabsorbed with peptidoglycan at $2^{\circ} \mathrm{C}$ suggesting that antibodies to peptidoglycan may be involved in activation of both the classical and alternative complement pathways. Thus, peptidoglycan appears to be the key cell wall component involved in staphylococcal opsonization, and it is suggested that host response to peptidoglycan, a major cell wall component of most gram-positive bacteria, may be related to the development of "natural immunity" to this group of microorganisms.
\end{abstract}

Dr. Quie is the American Legion Memorial Heart Research Professor.

Received for publication 4 August 1977 and in revised form 27 October 1977.

\section{INTRODUCTION}

In recent years increased attention has focused on the biological significance of the cell walls of gram-positive bacteria. In particular, peptidoglycan, a major component of the cell wall of most gram-positive bacteria, has been shown to play a significant role in determining the nature of host response to this group of bacteria $(1,2)$. In the case of Staphylococcus aureus, this cell wall component has been demonstrated to possess endotoxin-like properties (3), to activate the serum complement (C) system (4), and to elicit a cell-mediated immune response $(5,6)$. Few studies, however, have examined the role of the cell wall components of $S$. aureus in the process of opsonization, and results have been conflicting regarding the relative importance of these components in this process $(7-12)$.

In this investigation the role of the two major components of the $S$. aureus cell wall-the peptidoglycan and teichoic acid-in the process of opsonization was studied by measuring the uptake of radioactively labeled bacteria and purified cell wall components by human polymorphonuclear (PMN) leukocytes. The nature of the opsonic factors involved in this process and the kinetics of $\mathrm{C}$ activation were examined. Data is presented which demonstrates that opsonization by both heat-stable (IgG) and heat-labile serum factors is mediated by cell wall peptidoglycan. Peptidoglycan was found capable of activating both the classical and alternative pathways of the $\mathrm{C}$ system. It is proposed that $\mathrm{Cl}$ may play a role in activation of the alternative complement pathway by peptidoglycan and that activation of both the classical and alternative pathways is initiated by antigen-antibody complex formation.

\footnotetext{
${ }^{1}$ Abbreviations used in this paper: $\mathrm{CH}_{50}$, total hemolytic complement; HBSS, Hanks' balanced salt solution with $1 \%$ gelatin; PBS, phosphate-buffered saline; PMN, polymorphonuclear.
} 


\section{METHODS}

\section{Bacterial strains}

$S$. aureus strain $\mathrm{H}$, chosen because of its well-established cell wall structure (13), was kindly provided by Sir James Baddiley's laboratory, University of Newcastle-upon-Tyne, England. S. aureus $\mathrm{HSm}^{\mathrm{R}}$ (a spontaneous streptomycinresistant isolate of strain $\mathrm{H}$ ) and a teichoic acid-deficient mutant, strain 52A5 (14), were generously provided by J. T. Park, Tufts University, Boston, Mass. The cell wall of strain 52A5 appears to be composed almost entirely of peptidoglycan (15). The organisms were maintained on Trypticase Soy Agar (Difco Laboratories, Detroit, Mich.) slants.

\section{Cultivation and radioactive labeling of bacteria}

Bacteria were grown in peptone yeast extract broth (16) with aeration on an orbital shaker at $37^{\circ} \mathrm{C}$. For phagocytosis studies of intact bacteria, the organisms were labeled by inoculating several colonies of bacteria into $20 \mathrm{ml}$ peptone yeast extract broth containing $40 \mu \mathrm{Ci}\left[2{ }^{3} \mathrm{H}\right]$ glycine (sp act $5-15 \mathrm{Ci} / \mathrm{mmol}$, New England Nuclear, Boston, Mass.). After an 18-h incubation at $37^{\circ} \mathrm{C}$, the bacteria were washed three times in phosphatebuffered saline (PBS), pH 7.4, and resuspended in PBS to a final concentration of $1 \times 10^{9}$ colony-forming units $/ \mathrm{ml}$ using a spectrophotometric method confirmed by pour plate colony counts. For preparing radiolabeled cell walls, organisms were grown in peptone yeast extract broth, 2 liters containing $\left[2-{ }^{3} \mathrm{H}\right]$ glycine, $0.4 \mu \mathrm{Ci} / \mathrm{ml}$, and were harvested in late exponential growth phase $\left(\mathrm{OD}_{625 \mathrm{~nm}} 1.5-2.0\right.$, Spectronic 20, Bausch \& Lomb Scientific Optical Products Div., Rochester, N.Y.). Large scale growth of unlabeled bacteria (26 liters) was achieved in a New Brunswick Fermentor (New Brunswick Scientific Co., Inc., New Brunswick, N.J.) at $37^{\circ} \mathrm{C}$ with forced aeration (5 liters/min) using antifoam (Anti-Foam aerosol spray, Sigma Chemical Co., St. Louis, Mo.). 2 liters of a 15-h culture was used as an inoculum, and the bacteria were grown for $6-7 \mathrm{~h}$ and harvested at an $\mathrm{OD}_{625} \mathrm{~nm}$ of $1.0-1.5$. The cultures were harvested in a continuous flow centrifuge (Beckman J-21) using a JCF-2 rotor (Beckman Instruments Inc., Spinco Div., Palo Alto, Calif.) operating at 2,500 $\mathrm{g}$ with a flow rate of $250 \mathrm{ml} / \mathrm{min}$. The organisms were washed once in cold distilled water and then frozen $\left(-15^{\circ} \mathrm{C}\right)$ overnight before disruption. The yield was $80 \mathrm{~g}$ wet weight of cells from 26 liters of culture.

\section{Isolation of cell walls, peptidoglycan, and teichoic acid}

Unless otherwise indicated, all operations were carried out at $4^{\circ} \mathrm{C}$ and all centrifugations were at $16,319 \mathrm{~g}$ for $10 \mathrm{~min}$ at $4^{\circ} \mathrm{C}$. Washed organisms in distilled water were mixed with glass beads $(0.10-0.11 \mathrm{~mm}$, VWR Scientific Div., UNIVAR, San Francisco, Calif.), and disrupted by agitation in a Vibrogen Cell Mill (R.H.O. Scientific Inc., Commack, N. Y.) for $20 \mathrm{~min}$ at maximum speed. The glass beads were removed by filtration on a coarse glass sinter and the filtrate was centrifuged to deposit the white cell walls overlaying yellower, unbroken organisms. Care was taken to avoid resuspending unbroken organisms. The crude cell walls were washed once in distilled water, resuspended in $200 \mathrm{ml} 2 \%$ sodium dodecyl sulphate, and then stirred overnight at room temperature to inactivate autolytic enzymes and to aid in stripping of membrane components. The cell walls were then washed four times in water at room temperature before being resuspended in $200 \mathrm{ml}$ $0.05 \mathrm{M}$ Tris- $\mathrm{HCl}$ containing $\mathrm{MgCl}_{2}(5 \mathrm{mM})$ plus $2.5 \mu \mathrm{g} / \mathrm{ml}$ each of RNase (EC 3.1.3.4, 2,588 U/mg) and DNase (EC) 3.1.4.22, 2,500 U/mg) (each type 1 from Worthington Biochemical Corp., Freehold, N.J.) and incubated at $37^{\circ} \mathrm{C}$ for $1 \mathrm{~h}$ with gentle shaking $(100 \mathrm{rpm})$. To remove proteinaceous material including protein A (17), $200 \mu \mathrm{g} / \mathrm{ml}$, trypsin was added (EC 3.4.4.4, $189 \mathrm{U} / \mathrm{ml}$, Worthington Biochemical Corp.), and the incubation continued for $4 \mathrm{~h}$. The walls were washed once in water and then stirred with an equal volume of $80 \%$ phenol for $30 \mathrm{~min}$ at room temperature to remove lipoteichoic acid (18). After extraction, the walls were washed six times in water and then lyophilized. $1,680 \mathrm{mg}$ of cell wall was recovered from 26 liters of culture.

Cell walls $(1,260 \mathrm{mg})$ suspended in $75 \mathrm{ml}$ water were mixed with $75 \mathrm{ml}$ of $20 \%$ (wt/vol) TCA and were incubated at $60^{\circ} \mathrm{C}$ for $90 \mathrm{~min}$ to remove teichoic acid (19). The suspension was centrifuged to yield peptidoglycan which was washed four times with water before being lyophilized (yield 1,067 mg, $35.5 \%$ weight of wall removed.) Teichoic acid was recovered from the supernate by adding $750 \mathrm{ml}$ cold EtOH and allowing to stand at $4^{\circ} \mathrm{C}$ overnight. The precipitate recovered by centrifugation was resuspended in $14 \mathrm{ml} 10 \%$ TCA and allowed to precipitate again overnight at $4^{\circ} \mathrm{C}$ with $70 \mathrm{ml}$ EtOH. The product was washed twice with acetone and allowed to air dry.

Typically, cell walls were labeled to a specific activity of $\cong 5 \times 10^{5} \mathrm{cpm} / \mathrm{mg}$ dry weight. The hot TCA treatment resulted in about $10 \%$ loss of counts indicating little solubilization of glycine bridges occurred $(20)$ and the specific activity was roughly double that of the cell walls. Preparations were stored frozen at $-15^{\circ} \mathrm{C}$ at a concentration of $5-10 \mathrm{mg}$ dry weight $/ \mathrm{ml}$, and brief treatment in a sonic bath (Branson Sonic Power Co., Danbury, Conn.) was used to help attain an even suspension before each opsonization procedure.

\section{Chemical characterization of cell walls, peptidoglycan, and teichoic acid}

Quantitative examination. Carefully weighed cell walls, peptidoglycan, and teichoic acid were hydrolyzed in sealed tubes with $6 \mathrm{M} \mathrm{HCl}$ for $18 \mathrm{~h}$ at $105^{\circ} \mathrm{C}$. Acid was removed under vacuum over anhydrous $\mathrm{CaCl}_{2}$ in the presence of $\mathrm{NaOH}$ pellets; the dried residues were twice moistened with $0.5 \mathrm{ml}$ water and redried. Amino acids and amino sugars were estimated on an amino acid analyzer (Beckman model 120B Amino Acid Analyzer, Beckman Instruments, Fullerton, Calif. Inc.,). Phosphorus was estimated by the method of Fiske and Subba Row as described by Leloir and Gardini (21). Total fatty acids in $10-\mathrm{mg}$ amounts of preparation were determined as described by Wilkinson (22).

Qualitative examination. Teichoic acid (5 mg) was hydrolyzed in $2 \mathrm{M} \mathrm{HCl}$ for $3 \mathrm{~h}$ at $105^{\circ} \mathrm{C}$ in sealed tubes; acid was removed as described above. Part of the hydrolysate was treated with alkaline phosphatase (EC 3.1.3.1, $1 \mathrm{mg}$, type 1 , calf intestinal mucosa, Sigma Chemical Co.) in $0.025 \mathrm{M}$ $\mathrm{NH}_{4} \mathrm{HCO}_{3}$ containing $0.005 \mathrm{M} \mathrm{NH}_{4} \mathrm{OH}$, pH 8.3, overnight at $37^{\circ} \mathrm{C}$. Alkaline phosphatase-treated and untreated hydrolysates were examined by descending chromatography on Whatman no. 1 paper in the solvent systems 6 propan-1-Ol:3 $0.88 \mathrm{NH}_{3}: 1 \mathrm{H}_{2} \mathrm{O}$ (by volume) and 6 butan-1-Ol:4 pyridine: $3 \mathrm{H}_{2} \mathrm{O}$ (by volume) (23). Reducing compounds were detected with the alkaline $\mathrm{AgNO}_{3}$ reagent (24) and compounds with amino groups by ninhydin treatment $(0.25 \% \mathrm{wt} / \mathrm{vol}$ in acetone plus heating at $100^{\circ} \mathrm{C}$ for $5 \mathrm{~min}$ ). 


\section{Opsonic sources}

Serum was pooled from five healthy donors who denied previous staphylococcal infection (normal serum). To block $\mathrm{Cl}$, normal serum was chelated with ethylene glycotetraacetic acid in the presence of $\mathrm{MgCl}_{2}$ ( $\mathrm{MgEGTA}$ ) in a $10-\mathrm{M}$ to $10-\mathrm{mM}$ concentration with respect to serum (25). C2-deficient serum was obtained from a patient with genetically determined complete absence of $\mathrm{C} 2$ and normal levels of all other $\mathrm{C}$ components. Serum was stored in $0.5-\mathrm{ml}$ aliquots at $-70^{\circ} \mathrm{C}$. Heat-inactivated serum was prepared by heating thawed aliquots of serum at $56^{\circ} \mathrm{C}$ for 30 min. Purified human IgG was provided by Dr. D. Roos, Central Laboratory of the Blood Transfusion Service, Amsterdam, Netherlands. Serum and IgG were diluted to specified concentrations with Hank's balanced salt solution containing 1\% gelatin (HBSS) just before use. Calcium- and magnesium-free HBSS was used to dilute MgEGTA-chelated serum.

\section{Opsonization procedure}

According to Chatterjee $(26), \cong 1 \times 10^{8}$ whole organisms vield $25 \mu \mathrm{g}$ of cell walls. Consequently, $0.1-\mathrm{ml}$ aliquots of intact bacteria $\left(1 \times 10^{8}\right.$ colony-forming units) and $25 \mu \mathrm{g}$ of cell walls were used in all opsonization experiments. Studies using 25 and $12.5 \mu \mathrm{g}$ of peptidoglycan yielded similar findings; results were reported using $25 \mu \mathrm{g}$ of peptidoglycan. Each aliquot was incubated at $37^{\circ} \mathrm{C}$ in a $12 \times 75-\mathrm{mm}$ plastic tube, BioQuest, BBL \& Falcon Products, Becton, Dickinson \& Co., Cockeysville, Md., containing $1.0 \mathrm{ml}$ of the indicated opsonic source for specified times followed by centrifuging at $4,000 \mathrm{~g}$ for $15 \mathrm{~min}\left(4^{\circ} \mathrm{C}\right)$. The supernate was discarded and the pellet resuspended in $0.5 \mathrm{ml}$ HBSS.

\section{PMN leukocytes}

Blood from healthy donors was drawn into heparinized syringes (10 U heparin/ml blood). PMN leukocytes were prepared using a method modified from Böyum (27) in which the blood was centrifuged for $15 \mathrm{~min}$ at $200 \mathrm{~g}$, and the plasma-platelet layer was removed with a Pasteur pipette. The leukocyte layer was then withdrawn, placed in plastic tubes, and then diluted with two parts Spinner's Minimal Essential Medium (IX, Grand Island Biological Co., Grand Island, N. Y.). $8 \mathrm{ml}$ of this suspension was carefully layered onto $3 \mathrm{ml}$ Ficoll-Isopaque (lymphocyte separation medium, Litton Bionetics, Kensington, Md.). After centrifuging at $200 \mathrm{~g}$ for 30 min the mononuclear cell layer was removed with a Pasteur pipette. To obtain pure $\mathrm{PMN}$ leukocytes, the remaining medium was withdrawn and discarded, and $0.87 \% \mathrm{NH}_{4} \mathrm{Cl}$ in sterile water was added to the tube containing the erythrocyte-PMN leukocyte pellet which was then rotated for $10 \mathrm{~min}$ at room temperature. After centrifuging for $10 \mathrm{~min}$ at $160 \mathrm{~g}$, the PMN leukocyte pellet was washed an additional two times with $0.87 \% \mathrm{NH}_{4} \mathrm{Cl}$ to lyse the remaining erythrocytes. The PMN leukocytes were resuspended finally in HBSS and total and differential leukocyte counts were performed. The final leukocyte pellets were adjusted to a concentration of $10^{7}$ PMN leukocytes/ml HBSS. Contamination by mononuclear cells was evaluated by Wright's stained smears and generally. did not exceed $1 \%$.

\section{Phagocytosis mixtures and assays}

To each $0.5 \mathrm{ml}$ suspension of opsonized radioactively labeled intact bacteria, cell walls, and peptidoglycan, $0.5 \mathrm{ml}$ of
PMN leukocyte suspension was added. These mixtures were incubated at $37^{\circ} \mathrm{C}$ in an incubator shaker (New Brunswick Scientific Co., Inc.) at $250 \mathrm{rpm}$. PMN leukocyte uptake of bacteria, cell walls, and peptidoglycan was quantitated using a modification of a previously described method (28). Briefly, leukocyte-associated radioactivity was determined by taking duplicate $100-\mu$ l samples from each phagocytosis mixture at specified time intervals, placing the samples in $3 \mathrm{ml} \mathrm{PBS,} \mathrm{pH}$ 7.4 , in polypropylene vials (Bio-vials, Beckman Instruments Inc.,) and washing the leukocytes three times in PBS by differential centrifugation at $160 \mathrm{~g}$. Final pellets were resuspended in $3 \mathrm{ml}$ scintillation liquid (toluene containing fluoralloy [TLA, Beckman Instruments, Inc.] and $20 \%$ Biosolv-3 [Beckman Instruments, Inc.]) and counted in a liquid scintillation counter (Beckman LS-250). To determine total radioactivity (representing both leukocyte-associated and nonleukocyte-associated bacteria, cell walls, or peptidogly(an), duplicate $100-\mu \mathrm{l}$ samples were placed in $3 \mathrm{ml}$ PBS at the end of the assay period and centrifuged at $4,000 \mathrm{~g}$ for $15 \mathrm{~min}$. Supernates were discarded, pellets resuspended in scintillation liquid, and samples counted in the scintillation counter. An average of duplicate values was used in all calculations. PMN leukocyte uptake of radioactively labeled bacteria, cell walls, and peptidoglycan at given sampling times was calculated using the formula: \% uptake $=(\mathrm{cpm}$ in leukocyte pellet $) /($ total (pm) $\times 100$.

To study opsonization of soluble peptidoglycan fragments, purified peptidoglycan was digested with the muralytic enzyme, lysostaphin. $0.5 \mathrm{mg}(0.1 \mathrm{ml})$ peptidoglycan was incubated in $0.9 \mathrm{ml}$ PBS containing $10 \mu \mathrm{g} / \mathrm{ml}$ lysostaphin (Schwartz Mann Div., Becton, Dickinson \& Co., Orangeburg, N.Y.) for $60 \mathrm{~min}$ at $37^{\circ} \mathrm{C}$ followed by centrifuging at $10,000 \mathrm{~g}$ for $30 \mathrm{~min}$. Supernates were then heated in a boiling water bath for $15 \mathrm{~min}$ to inactivate lysostaphin. 50- $\mu \mathrm{l}$ aliquots of the supernate (peptidoglycan fragments) were then incubated with opsonic sources for $15 \mathrm{~min}$. PMN leukocytes were added, and uptake was determined as described above. Total radioactivity in these mixtures was determined by suspending $10(0)-\mu$ l samples directly into scintillation liquid. A control mixture of $0.5 \mathrm{mg}$ peptidoglycan was incubated in PBS for $60 \mathrm{~min}$; after centrifuging, the supernate was discarded and the pellet resuspended in $1.0 \mathrm{ml}$ PBS containing $10 \mu \mathrm{g} / \mathrm{ml}$ lysostaphin which had been previously heat-inactivated. This mixture was then heated in a boiling water bath after which $50-\mu$ laliquots were removed for opsonization and phagocytosis studies.

\section{Measurement of $C$ activation by purified peptidoglycan}

0.1-ml aliquots of peptidoglycan, at specified concentrations, and of water (control) were added to $12 \times 75-\mathrm{mm}$ plastic tubes (BioQuest, BBL \& Falcon Products) containing $1.0 \mathrm{ml}$ normal serum. After a 30 -min incubation at $37^{\circ} \mathrm{C}$, the tubes were centrifuged at $4,000 \mathrm{~g}$ for $15 \mathrm{~min}\left(4^{\circ} \mathrm{C}\right)$ and supernates were stored at $-70^{\circ} \mathrm{C}$ before measurement of total hemolytic complement $\left(\mathrm{CH}_{50}\right)$.

To study the kinetics of $\mathrm{C}$ activation in normal serum and in C2-deficient serum, $0.1-\mathrm{ml}(1.0 \mathrm{mg})$ aliquots of peptidoglycan were added to $1.0-\mathrm{ml}$ samples of serum followed by incubating at $37^{\circ} \mathrm{C}$ for indicated time intervals. Control mixtures containing $0.1 \mathrm{ml}$ distilled water were incubated simultaneously and removed at the same time intervals. After centrifuging at $4,000 \mathrm{~g}$ for $15 \mathrm{~min}\left(4^{\circ} \mathrm{C}\right)$, the supernates were stored at $-70^{\circ} \mathrm{C}$ before measurement of C3-C9.

The effect of preabsorption of normal and C2-deficient sera with peptidoglycan on the subsequent ability of peptidoglycan 
to activate the serum $C$ system was studied by incubating $1.0-\mathrm{ml}$ samples of serum three times for $60 \mathrm{~min}$ at $2^{\circ} \mathrm{C}$ with either $0.1-\mathrm{ml}(1.0 \mathrm{mg})$ aliquots of peptidoglycan or $0.1-\mathrm{ml}$ aliquots of distilled water (nonabsorbed serum). After each 60-min absorption period, samples were centrifuged for 15 min at $4,000 \mathrm{~g}\left(2^{\circ} \mathrm{C}\right)$ and the supernatant serum was added to the next precooled tube containing either peptidoglycan or water. After the final centrifugation, the serum samples were added to tubes containing $0.1-\mathrm{ml}$ aliquots of peptidoglycan, at indicated concentrations, and were then incubated at $37^{\circ} \mathrm{C}$ for specified time intervals. Control tubes containing absorbed and nonabsorbed serum and $0.1 \mathrm{ml}$ distilled water were likewise incubated at $37^{\circ} \mathrm{C}$. After incubation, samples were centrifuged at $4,000 \mathrm{~g}$ for $15 \mathrm{~min}\left(2^{\circ} \mathrm{C}\right)$ and the supernates stored at $-70^{\circ} \mathrm{C}$ before $\mathrm{C} 3-\mathrm{C} 9$ determination.

Hemolytic titrations of $\mathrm{C}$ were performed using sheep erythrocytes in acid citrate dextrose (Wilfer Laboratories, Stillwater, Minn.). Intermediate cell preparation $(\mathrm{C} \overline{14})$ and the assays of $\mathrm{CH}_{50}$ and $\mathrm{C} 3-\mathrm{C} 9$ were performed as previously described (29-32). For $\mathrm{CH}_{50}$, the optical density was read at $541 \mathrm{~nm}$ and for C3-C9 titration at $412 \mathrm{~nm}$. Results were expressed as $50 \%$ lysis, and titrations were corrected for day-to-day variations by including a known internal standard human serum.

\section{Electron microscopy}

Cell walls and peptidoglycan were examined by a Siemens 102 electron microscope (Siemens Corp., Medical/Industrial Groups, Istlin, N. J.) using previously described methods (33). In addition, $0.1-\mathrm{ml}$ aliquots of peptidoglycan $(1 \mathrm{mg})$ were incubated in plastic tubes (BioQuest, BBL \& Falcon Products) containing $1.0 \mathrm{ml} 10 \%$ normal serum, $10 \%$ heat-inactivated serum, and HBSS for $60 \mathrm{~min}$. After centrifuging for $15 \mathrm{~min}$ at $4,000 \mathrm{~g}$, supernates were discarded and $0.5 \mathrm{ml}$ HBSS was added to each tube. Leukocyte suspensions $(0.5 \mathrm{ml})$ were then added and the mixtures incubated for $15 \mathrm{~min}$ at $37^{\circ} \mathrm{C}$. The leukocytes were washed three times with cold PBS, fixed in $1.5 \%$ glutaraldehyde in PBS, and then thin sections were examined.

\section{RESULTS}

\section{Chemistry of the cell walls, peptidoglycan, and teichoic acid}

Table I shows the quantitative analysis for the cell wall preparations used in this study. It can be seen that amino acids other than those normally considered to be part of the staphylococcal peptidoglycan were either not detected or present in only small amounts. The lack of the full range of protein amino acids indicates little contamination of the cell walls with proteinaceous materials including protein $A$. On the basis of the analyses presented here, and knowledge of the $S$. aureus peptidoglycan structure $(19,34)$, it can be seen that the average subunit of the peptidoglycan contains isoglutamine, 1.0; lysine, 1.0; alanine, 2.0; glycine, 4.0; serine, $0.1 ; N$-acetylmuramic acid, $1.0 ; N$-acetylglucosamine, 1.0; O-acetyl, 0.6; and the formula weight is 1,138 . Using the lysine value it can be seen that $50.5 \%$ of the dry weight of the wall is accounted for by the peptidoglycan. For isolated peptidoglycan, $92.4 \%$ of the dry weight of the preparation is accountable for as peptidoglycan com-
TABLE I

Chemistry of Cell Walls, Peptidoglycan, and Teichoic Acid*

\begin{tabular}{lccc}
\hline \multicolumn{1}{c}{ Component } & Cell walls & Peptidoglycan & Teichoic acid \\
\hline & & nmol/mg & \\
Muramic acid & 180.4 & 280 & Trace \\
Glucosamine & 682 & 412 & 1,560 \\
Glutamic acid & 277 & 668 & 24 \\
Lysine & 444 & 812 & 48 \\
Alanine & 849 & 1,588 & 310 \\
Glycine & 1,826 & 3,460 & 120 \\
Serine & 48 & 68 & - \\
Phosphate & $1,00()$ & 84 & 2,000 \\
Aspartic acid & 26.4 & 24 & - \\
Threonine & 8.8 & 8 & - \\
Valine & 8.8 & 8 & - \\
Isoleucine & 8.8 & 8 & - \\
Leucine & 8.8 & 8 & - \\
Histidine & 30.8 & 20 & - \\
Arginine & 8.8 & 16 & \\
\hline
\end{tabular}

* Cell walls, peptidoglycan, and teichoic acid were isolated from $S$. aureus strain $\mathrm{H}$.

ponents. Assuming that ribitol phosphate and $N$-acetylglucosamine are equimolar then one can take ribitol, 1.0; phosphate, 1.0; $\mathrm{N}$-acetylglucosamine, 1.0; alanine, 0.16 as the average teichoic acid sub-unit (see below) and this gives a formula weight of 410 . Thus, $41 \%$ of the dry weight of the cell wall is present as teichoic acid plus $50.5 \%$ as peptiodglycan thereby accounting for $91.5 \%$ of the dry weight of the cell wall. It is likely that metal counterions to negatively charged groups in the teichoic acid and peptidoglycan make up a considerable portion of the unaccounted weight of these preparations (35). $82 \%$ of the teichoic acid preparation is accountable for as teichoic acid components.

Additional evidence that the peptidoglycan is free of teichoic acid is the finding that $95 \%$ of the cell wall phosphorus was removed by the hot TCA extraction and the ratio of the glucosamine to muramic acid changed from an excess to being almost equimolar.

Qualitative examination of the teichoic acid hydrolysate revealed components with chromatographic mobilities characteristic of glucosamine, ribitol, alanine, glucosaminitol phosphate, ribitol di- and monophosphate, and glucosaminitol ribitol. Amino acid analyses of the teichoic acid revealed glucosamine and alanine to be the major components. The absence of muramic acid and the low amounts of other amino acids show that the teichoic acid fraction does not contain major amounts of peptidoglycan. In an effort to determine whether the cell wall and peptidoglycan preparations were contaminated with lipoteichoic acid, the total fatty acid composition of the preparations was determined. Fatty acids are markers of cell membrane 


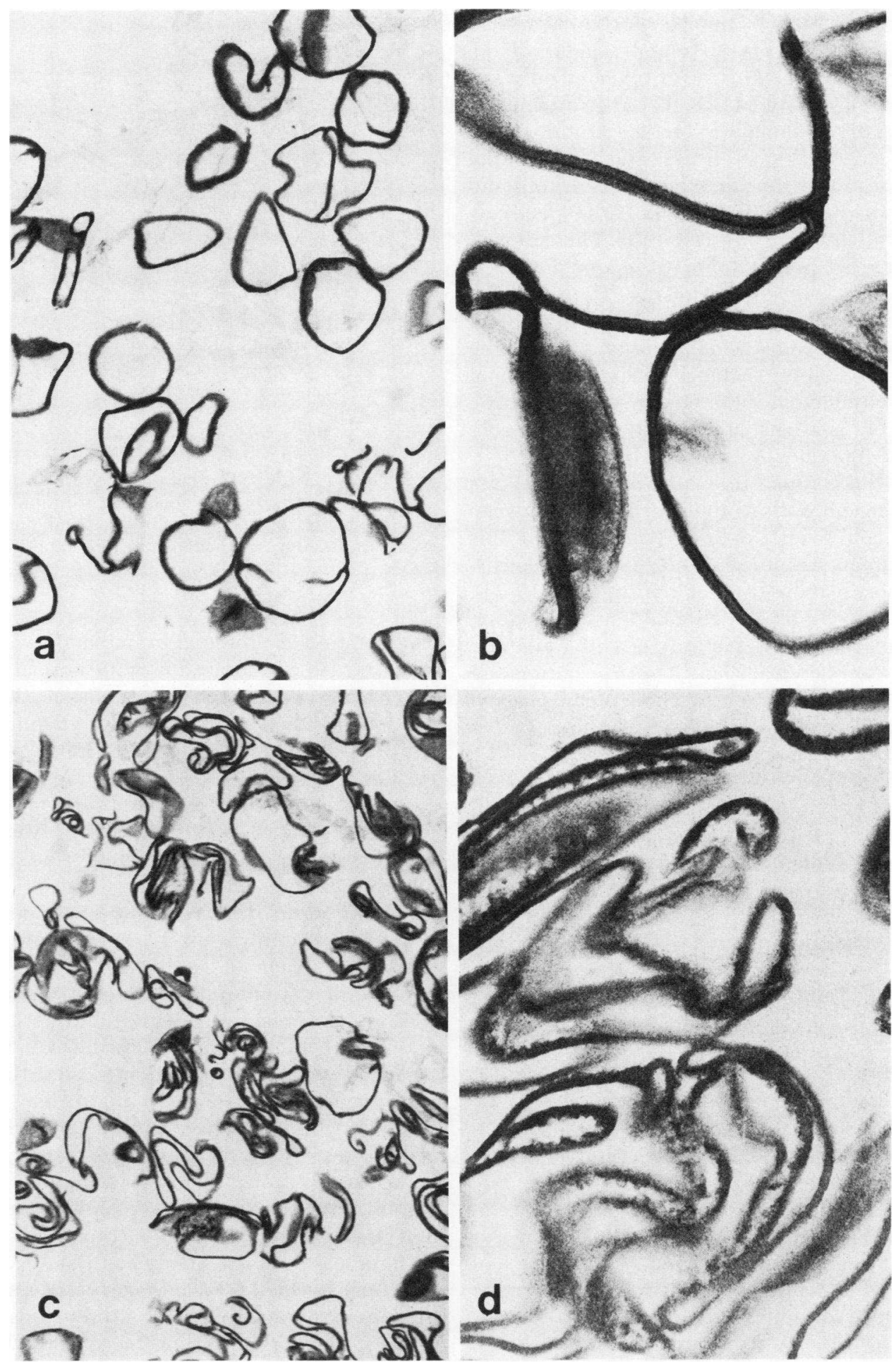

FIGURE 1 Electron micrographs of cell walls, $(a) \times 20,265,(b) \times 100,000$ and peptidoglycan, $(c)$ $\times 20,265,(d) \times 100,000$ isolated from $S$. aureus $\mathrm{H}$.

lipids and/or lipoteichoic acid. This was compared with the fatty acid composition of "crude cell walls" that had not been treated with sodium dodecyl sulfate, phenol, or enzymes but had simply been washed six times in water. Five major fatty acid methyl ester peaks were obtained from the crude cell walls by gas-liquid 
chromatography. Chromatography of the fatty acid methyl ester fraction from an equal weight of the purified cell walls used in this study revealed only one very small "peak" on the trace that was difficult to estimate. Similar examination of the peptidoglycan revealed two extremely small peaks. Summation of the total detector response revealed that the cell walls and peptidoglycan had at least 97.4 and $98.7 \%$, respectively less fatty acids than the crude cell walls. The cell wall and peptidoglycan preparations were contaminated with fatty acids at levels $<1 \mathrm{nmol} / \mathrm{mg}$. These results, plus the fact that we can account for most of the weight of the preparations in known components as well as the proven value of sodium dodecyl sulfate and phenol extractions in removing lipoteichoic acid $(18,36)$, indicate the preparations are not significantly contaminated with lipoteichoic acid.

Thus, the qualitative and quantitative analyses indicate that the cell walls (composed of peptidoglycan and teichoic acid) and peptidoglycan used in this investigation are highly purified and chemically consistent with the observations of other investigators $(15,34)$.

Electron micrographs of glutaraldehyde-osmium tetroxide-fixed, embedded sections of cell walls and peptidoglycan are shown in Fig. 1. The preparations are quite homogenous and devoid of whole organisms and debris. Both cell walls and peptidoglycan reveal a characteristic trilaminar appearance and septa (37). The morphologic appearance of the peptidoglycan is somewhat collapsed and folded in comparison to the cell walls. In general, the peptidoglycan is thinner in sectioned material than the cell walls, a finding in agreement with previous studies $(37,38)$; detailed morphometric measurements, however, were not performed.

\section{Phagocytosis of S. aureus H and of isolated cell walls and peptidoglycan}

Kinetics of uptake by PMN leukocytes. Intact S. aureus $\mathrm{H}$, isolated cell walls (peptidoglycan with covalently linked teichoic acid) and purified peptidoglycan were incubated with $1 \%$ normal serum, $1 \%$ heat-inactivated serum, and HBSS for 15 min before adding PMN leukocytes. As shown in Fig. 2, uptake of intact bacteria, cell walls, and peptidoglycan was similar at 3,10 , and $15 \mathrm{~min}$. At $15 \mathrm{~min}, \cong 70 \%$ of each of the three types of "particles" opsonized with normal serum were leukocyte-associated compared with $\cong 25 \%$ and virtually no uptake of particles which had been incubated with heat-inactivated serum and HBSS, respectively. These results suggested that removal of teichoic acid from the cell wall preparations did not significantly alter opsonization and phagocytosis by PMN leukocytes.

To determine whether leukocyte-associated radioactivity represented attached and/or ingested peptidogly-

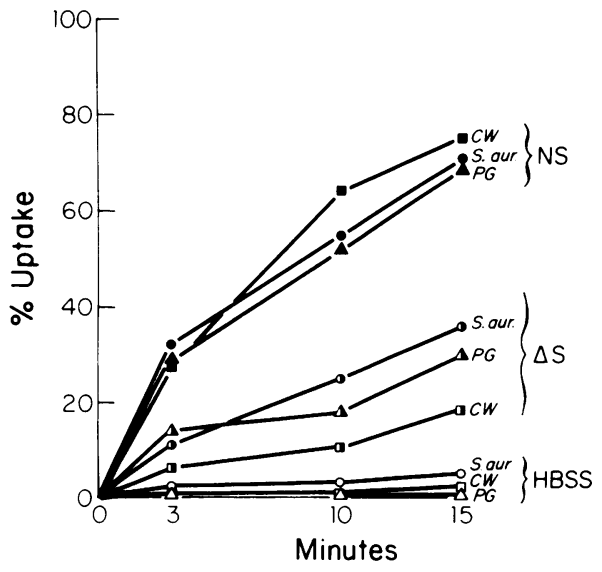

FIGURE 2 PMN leukocyte uptake of intact $S$. aureus $\mathrm{H}$ (S. aur), isolated cell walls (CW) and purified peptidoglycan (PG) preincubated with $1 \%$ normal serum (NS), $1 \%$ heat-inactivated serum $(\Delta S)$ and Hanks' balanced salt solution (HBSS) before adding leukocytes and determining uptake at 3,10 , and 15 min. Results represent means of three experiments.

can, electron microscope examination was performed (Fig. 3). After opsonization with normal serum, peptidoglycan was present within phagocytic vacuoles in the leukocytes and significant degranulation has occurred. When preincubated with HBSS, essentially no peptidoglycan was found within the leukocytes. Opsonization with heat-inactivated serum resulted in less ingestion than when normal serum was used as an opsonic source but in greater ingestion than when no opsonin was present (HBSS).

Opsonic titer of normal and heat-inactivated sera. When $1 \%$ serum was used as an opsonic source PMN leukocyte uptake of cell walls (peptidoglycan with teichoic acid) and peptidoglycan was found to be similar. This result, as stated above, suggested that removal of teichoic acid from the cell wall did not signifiantly affect opsonization. To test the possibility that removal of teichoic acid might change the titer of serum capable of effective opsonization, intact bacteria, cell walls, and peptidoglycan were incubated for $15 \mathrm{~min}$ with varying concentrations of normal serum and heat-inactivated serum before adding leukocytes and determining uptake at 15 min (Fig. 4). Phagocytosis of all three particles was significantly reduced and to the same extent when $0.1 \%$ normal serum and when $1.0 \%$ heat-inactivated serum were used as opsonic sources thereby demonstrating that the opsonic titer was not influenced by the removal of teichoic acid from the cell wall. When purified human IgG, in concentrations of $2.5,1.0,0.1$, and $0.01 \mathrm{mg} / \mathrm{ml}$, was used as an opsonic source, uptake was found to be similar to that of 5.0, 1.0, 0.1 , and $0.01 \%$ heat-inactivated serum, respectively (data not shown). This suggested that IgG was the major opsonic factor in heat-inactivated serum and implies 

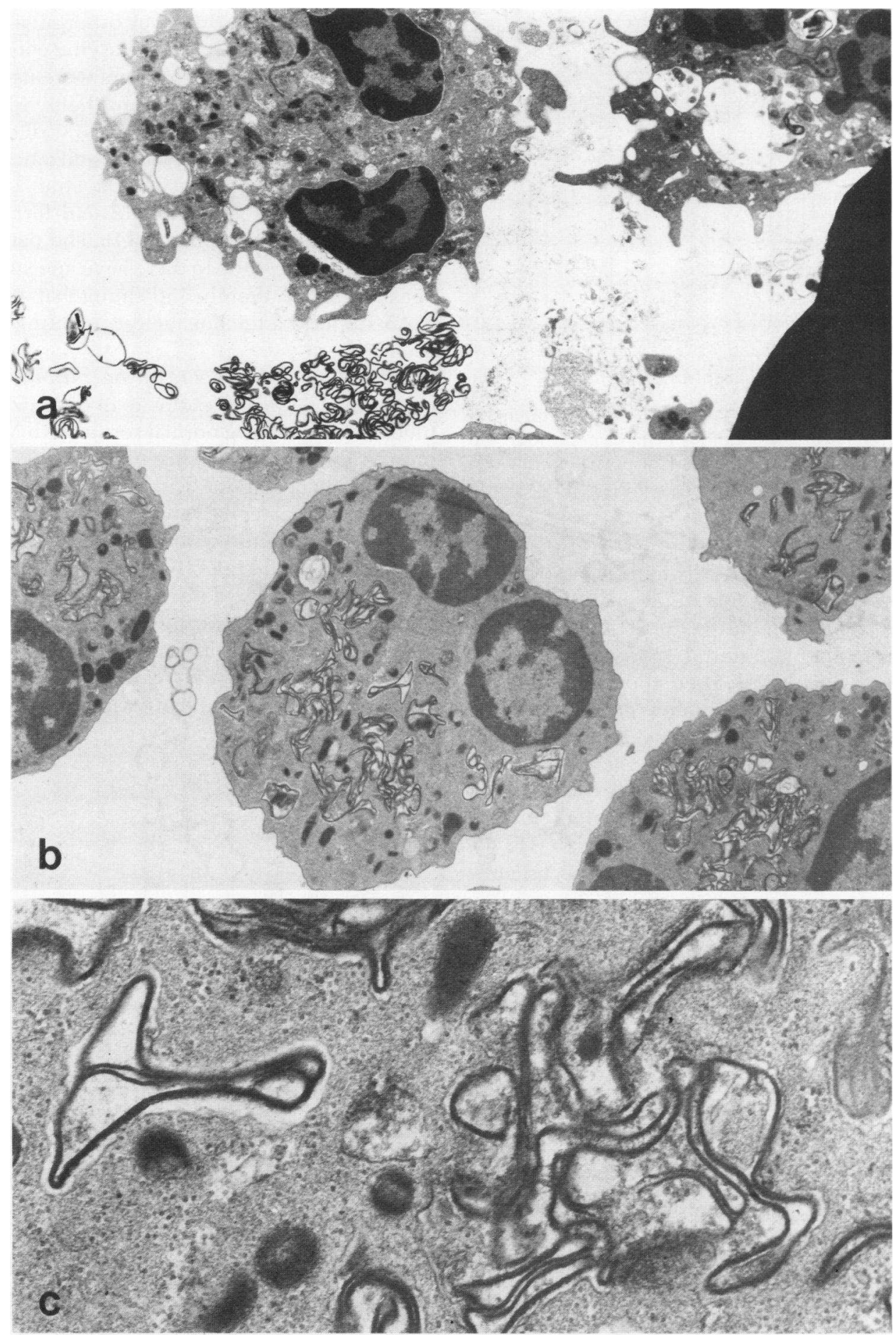

FIGURE 3 Electron micrographs of peptidoglycan after a 15-min incubation with PMN leukocytes. Peptidoglycan preincubated with HBSS remains extracellular, $(a) \times 7,500$; peptidoglycan preincubated with normal serum is present within phagocytic vacuoles and degranulation has occurred, $(b) \times 7,500,(c) \times 50,000$.

that purified human IgG contains antibodies against peptidoglycan.

Phagocytosis of S. aureus $\mathrm{HSm}^{\mathrm{R}}$ and 52A5. Al- though the results of the above experiments suggested that peptidoglycan was the major component involved in opsonization by normal and heat-inactivated sera, 


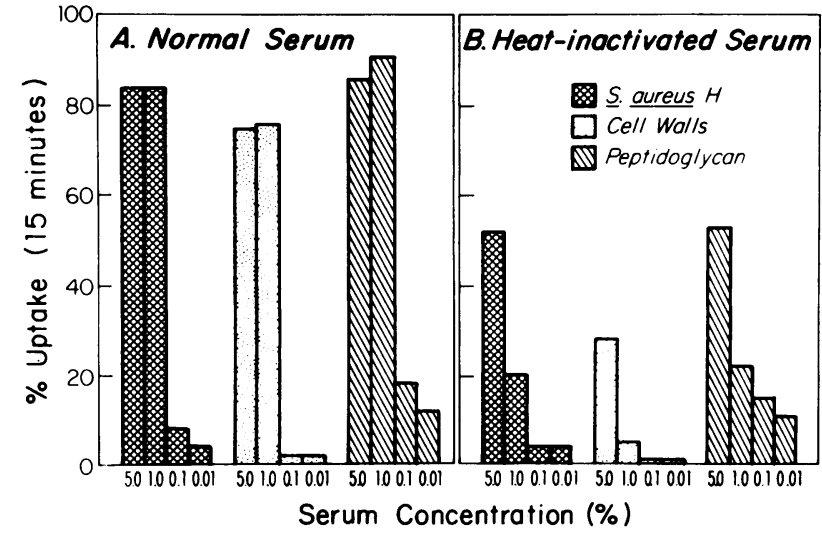

FIGURE 4 PMN leukocyte uptake at $15 \mathrm{~min}$ of intact $S$. aureus $\mathrm{H}$, isolated cell walls and purified peptidoglycan opsonized with varying concentrations of normal serum (A) and heat-inactivated serum (B). Results represent means of three experiments.

and that cell wall teichoic acid played little or no role in this regard, electron microscope studies of thin sections of cell walls and peptidoglycan (Fig. 1) had indicated that these preparations differed morphologically as well as in their previously defined chemical compositions. Therefore, it seemed possible that removal of teichoic acid from the cell wall might have affected opsonization independently of the change brought about in chemical makeup. To investigate this possibility, opsonization of a teichoic acid-deficient mutant (52A5) was compared to that of its parent strain $\left(\mathrm{HSm}^{\mathrm{R}}\right)$ (Fig. 5). As shown, phagocytosis of the teichoic

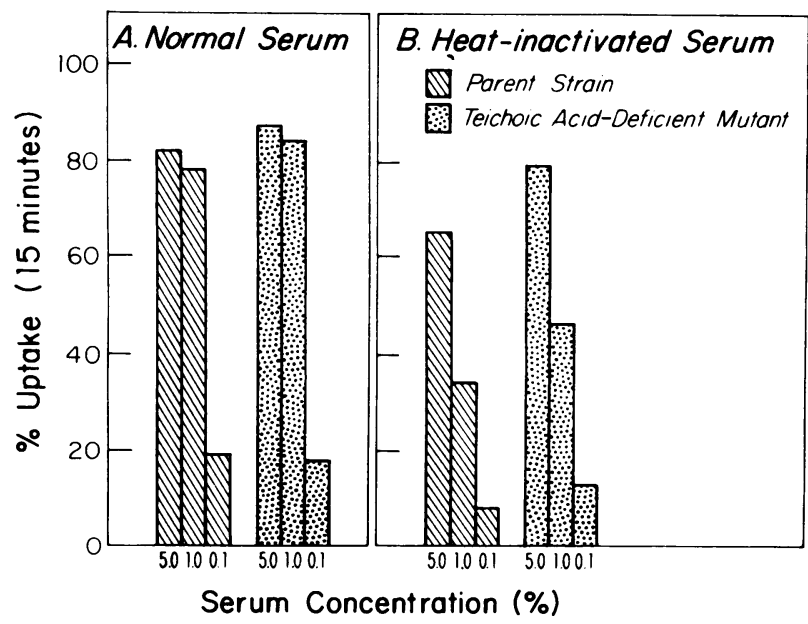

FigURE 5 PMN leukocyte uptake of $S$. aureus $\mathrm{HSm}^{\mathrm{R}}$ (parent strain) and 52A5 (teichoic acid-deficient mutant) preincubated with varying concentrations of (A) normal serum and (B) heat-inactivated serum before adding leukocytes and determining uptake at $15 \mathrm{~min}$. Results represent means of three experiments. acid-deficient mutant did not differ significantly from that of the parent strain when varying concentrations of normal and heat-inactivated sera were used as opsonic sources. This result provided further evidence that the teichoic acid component of the cell wall did not have a major influence on bacterial opsonization. After each experiment the typeability of the strains was checked with phage 52A (39). Teichoic acid forms part of the receptor site for this phage (14). The parent organism remained susceptible to this phage and strain $52 \mathrm{~A} 5$ was not susceptible, thereby indicating that reversion of the $52 \mathrm{~A} 5$ strain to a teichoic acid-containing form had not occurred.

The role of $C 1$ and $C 2$ in opsonization. To study the role of the classical $\mathrm{C}$ pathway in opsonization, $\mathrm{Cl}$ was blocked by chelating normal serum with MgEGTA, and opsonization in the absence of $\mathrm{C} 2$ was studied by using serum from a patient with complete C2 deficiency. Intact bacteria, cell walls, and peptidoglycan were incubated for $60 \mathrm{~min}$ with $1 \%$ concentrations of normal, heat-inactivated, MgEGTA-chelated, C2-deficient, and heat-inactivated $\mathrm{C} 2$-deficient sera before adding PMN leukocytes and measuring uptake at $15 \mathrm{~min}$. Normal serum was the most effective opsonic source for intact bacteria, cell walls, and peptidoglycan, uptake being significantly greater than when either MgEGTA-

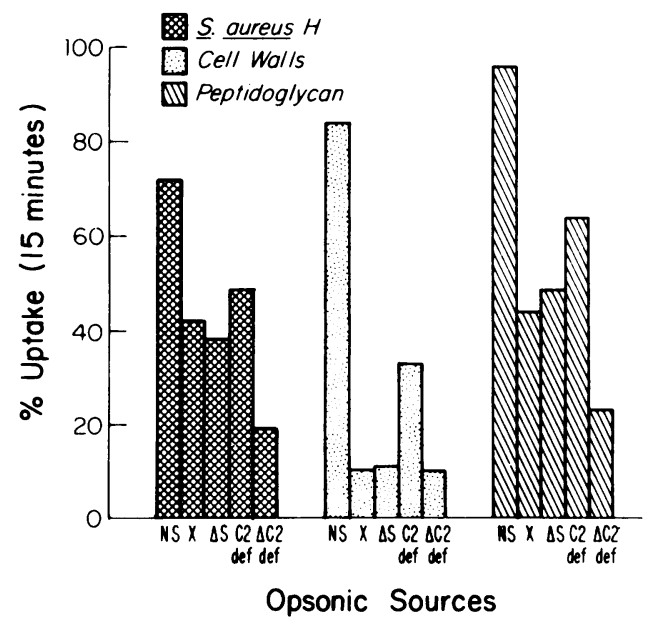

FigUre 6 PMN leukocyte uptake of intact $S$. aureus $\mathrm{H}$, isolated cell walls, and purified peptidoglycan preincubated for 60 min with normal serum (NS), MgEGTA-chelated serum $(\mathrm{X})$, heat-inactivated serum $(\Delta \mathrm{S}), \mathrm{C} 2$-deficient serum (C2 def) and heat-inactivated $\mathrm{C} 2$-deficient serum ( $\Delta \mathrm{C} 2$ def) before adding leukocytes and determining uptake at $15 \mathrm{~min}$. Results represent means of five experiments. Significance of differences in uptake comparing NS and X, P $<0.001$ for intact bacteria, cell walls and peptidoglycan; comparing NS and C2 def, $P<0.025,0.001,0.001$ for intact bacteria, cell walls and peptidoglycan respectively; comparing $\mathrm{C} 2$ def and $\Delta \mathrm{C} 2$ def, $P<0.001$ for intact bacteria, cell walls and peptidoglycan $(t$ test for paired data). 
chelated or C2-deficient sera were used as opsonic sources (Fig. 6). Although MgEGTA-chelated serum was not significantly more opsonic than heatinactivated serum, C2-deficient serum had a greater opsonic capacity than heat-inactivated C2-deficient serum.

These results suggested that opsonization could proceed via a heat-labile pathway other than the classical pathway when $\mathrm{C} 2$ was blocked but not when $\mathrm{C} 1$ was blocked. When the period of opsonization was limited to $15 \mathrm{~min}$ rather than $60 \mathrm{~min}$, however, C2-deficient serum was no more effective than heatinactivated C2-deficient serum as an opsonic source, opsonization with the other serum sources not being affected by the shorter opsonization period (data not presented). This finding indicated that opsonization via the second heat-labile pathway proceeded more slowly than when opsonization was carried out in the presence of the classical pathway.

Effect of lysostaphin treatment of peptidoglycan on opsonization. To determine whether relatively small, soluble fragments of peptidoglycan could be opsonized by normal and heat-inactivated sera, peptidoglycan was treated with lysostaphin and the fragments incubated with $10 \%$ normal serum, $10 \%$ heat-inactivated serum, and HBSS before adding PMN leukocytes and measuring leukocyte-associated radioactivity at 3,10 , and 15 $\min$. Whereas there was uptake of intact peptidoglycan in the control mixtures similar to that observed in earlier experiments (Fig. 2), no leukocyte-associated radioactivity was recorded when peptidoglycan fragments were studied. These results suggested that for effective opsonization a certain particle size of the peptidoglycan was required.

\section{C activation by peptidoglycan}

Effect of peptidoglycan concentration on $C$ activation in normal serum. As results from the above experiments indicated that the peptidoglycan of $S$. aureus $\mathrm{H}$ was the major $\mathrm{C}$-activating component of the cell wall, additional studies were performed in which consumption of $\mathrm{C}$ by peptidoglycan was measured. When purified peptidoglycan was incubated for $30 \mathrm{~min}$ with normal serum in concentrations of from 5.0 to 0.01 $\mathrm{mg} / \mathrm{ml}$ serum, a clear dose-response relationship was established (Table II). When concentrations of 1.0-5.0 $\mathrm{mg}$ were used, $\mathrm{CH}_{50}$ activity was not detectable.

Kinetics of $C$ activation in normal and C2-deficient sera. The ability of peptidoglycan to activate $\mathrm{C}$ in the presence and in the absence of $\mathrm{C} 2$ was studied by incubating normal and C2-deficient sera with peptidoglycan, at a concentration of $1.0 \mathrm{mg} / \mathrm{ml}$, at $37^{\circ} \mathrm{C}$. Samples were removed at 1-, 5-, 15-, 60-, and 120-min intervals and centrifuged at $2^{\circ} \mathrm{C}$. The hemolytic titer of C3-C9
TABLE II

Complement Activation in Normal Serum by Peptidoglycan *

\begin{tabular}{cc}
\hline Peptidoglycan & $\mathrm{CH}_{\mathbf{5 0}}$ \\
\hline \multicolumn{1}{c}{$m g$} & \\
5.0 & $<10 \ddagger$ \\
2.5 & $<10$ \\
1.0 & $<10$ \\
0.5 & 13 \\
0.1 & 25 \\
0.01 & 33 \\
Control & 31 \\
\hline
\end{tabular}

* $1-\mathrm{ml}$ aliquots of normal serum were incubated with equal volumes of purified peptidoglycan, in concentrations from 5.0 to $0.01 \mathrm{mg}$, and of water (control) for $30 \mathrm{~min}$ at $37^{\circ} \mathrm{C}$. After centrifuging, $\mathrm{CH}_{50}$ was measured in the supernatant serum. $t<10=$ not detectable.

was measured in the supernatant serum, and values were compared with C3-C9 levels measured in simultaneous controls (normal and C2-deficient sera incubated with water for the same time intervals). Consumption of C3-C9 in the peptidoglycan-treated samples was expressed as a percentage relative to the C3-C9 levels in the controls (Fig. 7). As shown, activation of complement occurred both in the presence (normal serum) and in the absence (C2-deficient serum) of an intact classical pathway; however, the rate of activation in C2-deficient serum was significantly slower than in normal serum (Fig. 7).

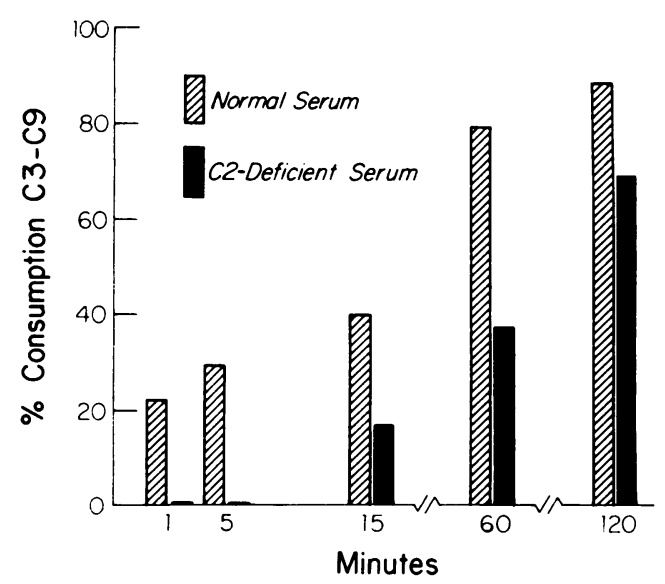

FIGURE 7 Kinetics of C activation by purified peptidoglycan in normal and $\mathrm{C} 2$-deficient sera. 1-ml aliquots of normal and $\mathrm{C} 2$-deficient sera were incubated at $37^{\circ} \mathrm{C}$ with equal volumes of water (controls) and peptidoglycan (1.0 mg) for $1,5,15,60$, and $120 \mathrm{~min}$. Consumption of $\mathrm{C} 3-\mathrm{C} 9$ in the peptidoglycantreated serum samples is expressed as a percent of the simultaneous control samples. 
Effect of preabsorption of serum with peptidoglycan on subsequent $C$ activation. The ability of peptidoglycan to activate the $\mathrm{C}$ system in normal serum was found to be significantly impaired when serum was preabsorbed with peptidoglycan at $2^{\circ} \mathrm{C}$. Although there was 92,89 , and $37 \%$ consumption of C3-C9 in control serum after a 30-min incubation with 5.0, 1.0, and 0.1 $\mathrm{mg}$ peptidoglycan, respectively, there was $<25 \%$ C3-C9 consumption in serum that had been preabsorbed with peptidoglycan. Likewise, preabsorption of C2-deficient serum with peptidoglycan at $2^{\circ} \mathrm{C}$ had an inhibitory effect on the subsequent capacity of peptidoglycan to activate the C system. After 30-min and 60-min incubations with $1.0 \mathrm{mg}$ peptidoglycan, there was 9 and 44\% C3-C9 consumption in nonabsorbed C2-deficient serum compared with 0 and $27 \%$ activation in C2-deficient serum which had been preabsorbed with peptidoglycan. The absorption procedure itself did not significantly influence C3-C9 levels (after absorption, C3-C9 levels were 422 and $540 \mathrm{U} / \mathrm{ml}$ in normal and C2-deficient sera compared with control values of 437 and $500 \mathrm{U} / \mathrm{ml}$, respectively). These data suggested that peptidoglycan activation of the $\mathrm{C}$ system, via both the classical and alternative pathways, depended upon the presence of an absorbable, noncomplement-related serum factor.

\section{DISCUSSION}

The cell wall of most $S$. aureus strains is composed of three major constituents-peptidoglycan, teichoic acid, and protein $\mathrm{A}$. The peptidoglycan component is a linear polymer of repeating $\beta$-1-4-linked $N$-acetylglucosamine and $N$-acetylmuramic acid residues. Attached to the carboxyl group of each $N$-acetylmuramic acid is a tetrapeptide cross-linked by a pentaglycine bridge to a neighboring peptide unit. Approximately $50 \%$ of the weight of the cell wall is contributed by peptidoglycan, and it is this component which provides the wall its basic rigidity (40). Cell wall teichoic acids, comprising $\cong 40 \%$ of cell wall weight, are charged polymers of ribitol-phosphate linked to muramic acid residues of the peptidoglycan (41). Protein A, contributing $\cong 5 \%$ to cell wall weight, is a protein with unique properties which, in general, interfere with the process of opsonization $(42,43)$. In this investigation, trypsin digestion was used to remove protein $\mathrm{A}$ and other cell wall proteins. Also lipoteichoic acid, which may be another component of the staphylococcal cell surface (18), was extracted, and the two major constituents of the cell wall-peptidoglycan and teichoic acid-were studied. The staphylococcal cell surface may be viewed as a mosaic of different domains where all of the major cell wall components, including peptidoglycan and teichoic acid, can be sufficiently exposed to interact with external factors.
The relative importance of the peptidoglycan and teichoic acid components of the $S$. aureus cell wall in the process of opsonization has been a matter of controversy. Evidence has previously been presented supporting the role of both teichoic acid (7-10) and peptidoglycan $(11,12)$ in this regard. These studies, however, have used indirect methods to assess opsonization, either by immunizing animals with cell wall components and measuring the protective effect of such immunization $(8,9)$ or by absorbing serum with cell wall components and determining the effect of such absorption on serum opsonic activity $(7,11,12)$.

In this study, PMN leukocyte uptake of intact $S$. aureus $\mathrm{H}$ and of highly purified cell walls-composed of peptidoglycan and teichoic acid-and of isolated peptidoglycan was measured quantitatively using $\left[{ }^{3} \mathrm{H}\right]$ glycine-labeled bacteria, cell walls, and peptidoglycan. When normal human serum and heat-inactivated serum were used as opsonic sources, intact bacteria, cell walls, and peptidoglycan were taken up by PMN leukocytes in a similar manner. All three particles were most efficiently opsonized by normal serum, and uptake did not occur in the absence of serum factors. Electron microscope studies revealed that opsonized peptidoglycan was readily ingested by PMN leukocytes. Studies with purified IgG indicated that IgG was the major heat-stable serum opsonic factor, a finding reported by other investigators (44-46) for different staphylococcal strains.

As isolated cell walls (peptidoglycan and teichoic acid) and purified peptidoglycan were phagocytized in a comparable fashion, it appeared that the removal of teichoic acid from the cell wall did not significantly affect opsonization, thereby implying that the process of opsonization was primarily mediated by peptidoglycan. Electron microscope studies, however, had revealed that the cell wall and peptidoglycan preparations were not morphologically identical; in thin sections the peptidoglycan was, in general, more collapsed. Therefore, the possibility existed that this structural difference might influence opsonization in a manner independently of the well-defined chemical difference of these particles. To help clarify this possibility, opsonization of a teichoic acid-deficient mutant strain of $S$. aureus $\mathrm{H}$ was compared with that of the parent strain. The absence of teichoic acid in the cell wall did not alter opsonization by normal and heat-inactivated sera which added support to the hypothesis that teichoic acid played an insignificant role in bacterial opsonization.

The finding that there was no PMN leukocyte uptake of lysostaphin-degraded peptidoglycan which had been preincubated with normal and heat-inactivated sera suggested that a certain particle size is required for effective opsonization. Shayegani and colleagues (11) reported similar findings using different methods and 
enzymes. Grov and co-workers (47) have recently demonstrated that the inhibition of leukocyte migration by staphylococcal peptidoglycan is also dependent upon the size of the peptidoglycan fragment.

Other investigators have demonstrated that the classical $(46,48)$ and the alternative $(46,49,50) \mathrm{C}$ pathways are involved in staphylococcal opsonization. In an attempt to delineate which heat-labile serum factors participated in the opsonization of S. aureus $\mathrm{H}$ and of the peptidoglycan component, phagocytosis of intact bacteria, cell walls, and peptidoglycan was measured after opsonization with normal, MgEGTAchelated, heat-inactivated, C2-deficient, and heatinactivated C2-deficient sera. Opsonization of all three particles was optimal when normal serum was used as an opsonic source. In the absence of $\mathrm{C} 2$, opsonization was less effective, both the opsonic capacity and the rate of opsonization being less with $\mathrm{C} 2$-deficient serum than with normal serum; however, opsonization did proceed via a heat-labile system (the opsonic capacity of C2-deficient serum being significantly reduced by heat-inactivation). On the other hand, heat-labile opsonic activity was abolished in the absence of $\mathrm{Cl}$ (MgEGTA-chelated serum).

These results suggest that opsonization of intact $S$. aureus $\mathrm{H}$ and of peptidoglycan is most effective in the presence of an intact classical pathway. However, it appears that opsonization can proceed via another heat-labile pathway when $\mathrm{C} 2$ is blocked but not when C1 is blocked. Other investigators $(51,52)$ have demonstrated that $\mathrm{Cl}$ can play a role in the activation of the alternative complement pathway (the "Cl-bypass" mechanism). From the results in this study, it appears that the C1-bypass may be operative in the opsonization of $S$. aureus $\mathrm{H}$ peptidoglycan by $\mathrm{C} 2$-deficient serum, and that blocking $\mathrm{C} 1$ thereby interferes with alternative pathway activation.

Activation of the serum C system by peptidoglycan was further studied by incubating peptidoglycan with normal serum and measuring $\mathrm{C}$ consumption. A doseresponse relationship was established in which $\mathrm{CH}_{50}$ was not detectable after a 30-min incubation with peptidoglycan in concentrations of $1.0-5.0 \mathrm{mg} / \mathrm{ml}$ serum. The kinetics of $\mathrm{C}$ activation were then investigated using normal and C2-deficient sera. Although the rate of C3-C9 consumption was significantly faster and proceeded to a greater degree in normal serum, C3-C9 was also consumed in C2-deficient serum. These findings were consistent with observations made in the functional phagocytosis assay wherein C2-deficient serum was not as effective as normal serum as an opsonic source and opsonization proceeded at a slower rate in C2-deficient serum than in normal serum. Similar findings have been reported in studies of opsonization of other staphylococcal strains $(28,42)$. Recently, Bokisch (53) has reported that peptidoglycans from
Streptococcus group A, Staphylococcus epidermidis, and Micrococcus lysodeikticus were capable of activating both the classical and the alternative $\mathrm{C}$ pathways in human serum. Pryjma and colleagues (4) have demonstrated the same capacity for $S$. aureus peptidoglycan using serum from guinea pigs and mice.

In an attempt to determine whether S. aureus peptidoglycan was capable of directly activating the classical and alternative $C$ pathways or whether $C$ activation was initiated by antigen-antibody complex formation, normal and C2-deficient sera were preabsorbed with peptidoglycan at $2^{\circ} \mathrm{C}$ before adding peptidoglycan at $37^{\circ} \mathrm{C}$ and measuring $\mathrm{C} 3-\mathrm{C} 9$ consumption. Preabsorption of both serum sources with peptidoglycan was found to limit the ability of peptidoglycan to subsequently activate the classical and alternative pathways of $\mathrm{C}$. These preliminary findings suggest that $\mathrm{C}$ activation by peptidoglycan depends upon the presence of an absorbable, noncomplement-related factor, presumably immunoglobulin. Wheat and coworkers (54) have presented data to support this hypothesis. Activation of the classical $\mathrm{C}$ pathway, in general, is known to be initiated by the combining of IgG or IgM with antigen (55). There is a growing body of evidence which suggests that, in certain systems, activation of the alternative complement pathway may likewise depend upon antigen-antibody formation $(46,56,57)$. Antibodies of the IgG class, to $S$. aureus peptidoglycan have been shown to be present in normal human serum (58). However, there is a need for studies utilizing purified $\mathrm{C}$ components to evaluate the possibility that peptidoglycan may directly interact with $\mathrm{Cl}$ and/or directly activate the alternative $\mathrm{C}$ pathway as described for certain gram-negative bacterial cell wall components (59).

Over the past decade it has been demonstrated that the recognition of staphylococci by PMN leukocytes is mediated by receptors within the phagocytic membrane with specificity for the $\mathrm{Fc}$ fragment of IgG and for an activated form of the third component of C, C3b (60, 61). Staphylococcal peptidoglycan would appear to play a central role in the initiation of this recognition process. Other investigators $(1,62)$ have proposed that the peptidoglycan, a major cell wall component of most gram-positive bacteria, may play a significant role in the development of "natural immunity" to this group of microorganisms. Recognition of all gram-positive bacteria may, therefore, be a manifestation of host response to this common cell wall component.

It should be emphasized that although cell wall teichoic acid was found not to be important in promoting opsonization in the serum sources used in this study, the possibility remains that teichoic acid is of importance in fostering opsonization in serum from patients with $S$. aureus infections in which increased levels of teichoic acid antibodies have been demon- 
strated (6:3). Future studies will be directed at investigating this possibility.

\section{ACKNOWLEDGMENTS}

The authors are grateful to D. Peterson for the amino acid analyses, to Patti Lorenz for her secretarial assistance, and to L. D. Sabath for his valuable discussion and support.

This work was supported by U. S. Public Health Service grants AI 06931-11, AI-08821-(07, AI 12478-(03, AI 10704, and HL 06314; a grant from the Kroc Foundation; and a Grant-in-Aid from the Graduate School, University of Minnesota.

\section{REFERENCES}

1. Krause, R. M. 1975. Immunological activity of the peptidoglycan. Z. Immunitaetsforsch. Exp. Klin. Immunol. 149: 1.36-150.

2. Heymer, B., K. H. Schleifer, S. Read, J. B. Zabriskie, and R. M. Krause 1976. Detection of antibodies to bacterial cell wall peptidoglycan in human sera. J. Immunol. 117: $23-26$.

3. Rotta, J. 1975. Endotoxin-like properties of the peptidoglycan. Z. Immunitaetsforsch. Exp. Klin. Immunol. 149: 230-244.

4. Pryjma, J., K. Pryjma, A. Grov, and P. B. Heczko. 1976. Inmunological activity of staphylococcal cell wall antigens. In Staphylococci and Staphylococcal Diseases. J. Jeljaszewicz, editor. Gustav Fischer Verlag, New York, $87.3-881$

5. Kowalski, J. J., and D. T. Berman. 1971. Immunobiologi(al activity of cell wall antigens of Staphylococcus aureus. Infect. Immun. 4: 205-211.

6. Targowski, S. P., and D. T. Berman. 1975. Cell-mediated immune reactions in vitro to cell walls and peptidoglycan from Staphylococcus aureus. Z. Immunitaetsforsch. Exp. Klin. Immunol. 149: 295-301.

7. Mudd, S., A. Yoshida, I. W. Li, and N. A. Lenhart. 1963. Identification of a somatic antigen of Staphylococcus aureus critical for phagocytosis by human blood leuko(ytes. Science (Wash. D. C.). 199: 1200-1201.

8. Ekstedt, R. D. 1963. Studies on immunity to staphylococcal infection in mice. II. Effect of immunization with fractions of Staphylococcus aureus prepared by physical and chemical methods. J. Infect. Dis. 112: 152-157.

9. Ekstedt, R. D. 1965. Mechanisms of resistance to staphylococcal infection: natural and acquired. Ann. N. Y. Acad. Sci. 128: 301-334.

10. Ekstedt, R. D. 1974. Immune response to surface antigens of Staphylococcus aureus and their role in resistance to staphylococcal disease. Ann. N. Y. Acad. Sci. 236: $203-220$.

11. Shayegani, M., K. Hisatsune, and S. Mudd. 1970. Cell wall component which affects the ability of serum to promote phagocytosis and killing of Staphylococcus aureus. Infect. Immun. 2: 750-756.

12. Humphreys, D. W., L. J. Wheat, and A. White. 1974. Staphylococcal heat-stable opsonins. J. Lab. Clin. Med. 84: $122-128$.

13. Archibald, A. R. 1972. The chemistry of staphylococcal cell walls. In The Staphylococci. J. O. Cohen, editor. Wiley-Interscience, Div., John Wiley \& Sons, Inc., New York. 75-109.

14. Chatterjee, A. N., D. Mirelman, H. J. Singer, and J. T. Park. 1969. Properties of a novel pleiotropic bacteriophage- resistant mutant of Staphylococcus aureus. I. Bacteriol. 111: $272-283$.

15. Shaw, D. R. D., D. Mirelman, A. N. Chatterjee, and J. T Park. 1970. Ribitol teichoic acid synthesis in bacteriophage-resistant mutants of Staphylococcus aureus H J. Biol. Chem. 245: 5101-5106.

16. Gilpin, R. W., A. N. Chatterjee, and F. E. Young. 1972. Autolysis of microbial cells: salt activation of autolytic enzymes in a mutant of Staphylococcus aureus. I. Bacteriol. 111: 272-28.3.

17. Sjöquist, J. 1973. Structure and immunology of protein A. In Contributions to Microbiology and Immunology. Staphylococei and Staphylococcal Infections. I. Jeljaszewicz, editor. S. Karger, Basel. 1: 83-92.

18. Wicken, A. J., and K. W. Knox. 1975. Lipoteichoic acids: a new class of bacterial antigens. Science (Wash. D. C.). 187: $1161-1167$.

19. Tipper, D. J., and M. F. Berman. 1969. Structures of the cell wall peptidoglycans of Staphylococcus epidermidis Texas 26 and Staphylococcus aureus Copenhagen. I. Chain length and average sequence of cross-bridge peptides. Biochemistry. 8: 2183-2191.

20. Schliefer, K. H. 1975. Chemical structure of the peptidoglycan, its modificability and relation to the biological activity. Z. Immunitaetsforsch. Exp. Klin. Immunol. 149: $104-117$.

21. Leloir, L. F., and C. E. Gardini. 1957. Characterization of phosphorus compounds by acid lability. Methods Enzymol. 3: 840-850.

22. Wilkinson, B. J. 1977. Cell envelope of Paracoccus dentrificans: outer membrane permeability to lysozyme and hydrophobic antibiotics. FEMS Microbiol. Lett. 2: 285-288.

23. Baddiley, J., J. G. Buchanan, U. L. Rajbhandary, and A. R. Sanderson. 1962. Teichoic acid from the walls of Staphylococcus aureus $\mathrm{H}$ : structure of the $\mathrm{N}$-acetylglucosaminyl residues. Biochem. J. 82: 439-448.

24. Trevelyan, W. E., D. P. Procter, and J. S. Harrison. 1950. Detection of sugars on paper chromatograms. Nature (London). 166: 444-445.

25. Forsgren, A., R. H. McLean, A. F. Michael, and P. G. Quie. 1975. Studies of the alternate pathway in chelated serum. J. Lab. Clin. Med. 85: 904-912.

26. Chatterjee, A. N. 1969. Use of bacteriophage-resistant mutants to study the nature of the bacteriophage receptor site of Staphylococcus aureus. J. Bacteriol. 98: 519-527.

27. Böyum, A. 1968. Isolation of mononuclear cells and granulocytes from human blood. Scand. J. Clin. Lab. Invest. Suppl. 97, 21: 77-89.

28. Verhoef, J., P. K. Peterson, and P. G. Quie. 1977. Kinetics of staphylococcal opsonization, attachment, ingestion and killing by human polymorphonuclear leukocytes: a quantitative assay using ${ }^{3} \mathrm{H}$-thymidine labeled bacteria. $J$. Immunol. Methods. 14: 303-311.

29. Gewurz, J., A. R. Page, R. J. Pickering, and R. Good. 1967. Complement activity and inflammatory neutrophil exudation in man: studies in patients with glomerulonephritis, essential hypocomplementemia and agammaglobulinemia. Int. Arch. Allery Appl. Immunol. 32: 64-90.

30. Nelson, R. A., Jr., J. Jensen. I. Gigli, and N. Tamura. 1966. Methods for separation, purification and measurement of nine components of hemolytic complement in guinea pig serum. Immunochemistry. 3: 111-135.

31. Borsos, T., and H. Rapp. 1967. Immune hemolysis: a simplified method for the preparation of EAC4 with guinea pig or with human complement. J. Immunol. 99: $263-268$ 
32. McLean, R. G., H. Geiger, B. Burke, R. Simmons, J. Najarian, R. L. Vernier, and A. F. Michael. 1976. Recurrence of membranoproliferative glomerulonephritis following kidney transplantation. Am. J. Med. 60: 60-72.

33. Schopfer, K., and S. D. Douglas. 1976. Fine structural studies of peripheral blood leukocytes from children with Kwashiorkor: morphological and functional properties. Br. J. Haematol. 32: 573-577.

34. Rogers, H. J. 1974. Peptidoglycans (mucopeptides): structure, function and variations. Ann. N. Y. Acad. Sci. 235: $29-51$

35. Heptinstall, S., A. R. Archibald, and J. Baddiley. 1970. Teichoic acids and membrane function in bacteria. Nature (Lond.). 225: 519-521.

36. Knox, K. W., and A. J. Wicken. 1972. Serological studies on the teichoic acids of Lactobacillus plantarum. Infect. Immun. 6: 43-49.

37. Millward, G. R., and D. A. Reaveley. 1974. Electron microscope observations on the cell walls of some gram-positive bacteria. J. Ultrastruct. Res. 46: 309-326.

38. Garland, J. M., A. R. Archibald, and J. Baddiley. 1975. An electron microscopic study of the location of teichoic acid and its contribution to straining reactions in walls of Streptococcus faecalis 8191.J. Gen. Microbiol. 89: 73-86.

39. Blair, J. E., and R. E. O. Williams. 1961. Phage typing of staphylococci. Bull. W. H. O. 24: 771-784.

40. Ghuysen, J. M., Strominger, and D. J. Tipper. 1968. Bacterial cell walls. Compr. Biochem. 26: 53-104.

41. Heckels, J. E., A. R. Archibald, and J. Baddiley. 1975. Studies on the linkage between teichoic acid and peptidoglycan in a bacteriophage-resistant mutant of Staphylococcus aureus H. Biochem. J. 149: 637-647.

42. Forsgren, A., and P. G. Quie. 1974. Effects of staphylococcal protein A on heat-labile opsonins. J. Immunol. 112: $1177-\mathrm{i} 180$.

43. Peterson, P. K., J. Verhoef, L. D. Sabath, and P. G. Quie. 1977. The effect of protein A on staphylococcal opsonization. Infect. Immun. 15: 760-764.

44. Laxdal, T., R. P. Messner, R. C. Williams, and P. G. Quie. 1968. Opsonic, agglutinating and complement-fixing antibodies in patients with subacute bacterial endocarditis. J. Lab. Clin. Med. 71: 638-653.

45. Downey, R. J. 1973. Opsonization of Staphylococcus aureus by guinea pig $7 \mathrm{~S}$ gammaglobulin.Jpn.J. Microbiol. 17: 339-344.

46. Verhoef, J., P. K. Peterson, Y. Kim, L. D. Sabath, and P. G. Quie. 1977. Opsonic requirements for staphylococcal phagocytosis: heterogeneity among strains. Immunology. 33: $191-197$.

47. Grov, A., S. Helgeland, and C. Endressen. 1976. Inhibition of leukocyte migration by peptidoglycan fragments. In Staphylococci and Staphylococcal Diseases. J. Jeljaszewicz, editor. Gustav Fischer Verlag, New York. 389392.
48. Forsgren. A., and P. G. Quie. 1974. Influence of the alternate complement pathway on opsonization of several bacterial species. Infect. Immun. 10: 402-404.

49. Jasin, H. E. 1972. Human heat-labile opsonins: evidence for their mediation via the alternate pathway of complement activation. J. Immunol. 109: 26-31.

50. Johnson, F. R., V. Agnello, and R. C. Williams. 1972. Opsonic activity in human serum deficient in C2. J. Immunol. 109: 141-145.

51. May, J. E., and M. M. Frank. 1973. A new complementmediated cytolytic mechanism - the Cl-bypass activation pathway. Proc. Natl. Acad. Sci. U.S.A. 70: 649-652.

52. Volankis, J. E., D. Schultz, and R. M. Stroud. 1976. Evidence that $\mathrm{Cls}$ participates in the alternative complement pathway. Int. Arch. Allergy Appl. Immunol. 50: $68-80$.

53. Bokisch, V. 1975. Interaction of peptidoglycans with anti-IgGs and with complement. Z. Immunitaetsforsch, Exp. Klin. Immunol. 149: 320-330.

54. Wheat, L. J., D. W. Humphreys, and A. White. 1974. Opsonization of staphylococci by normal human sera: the role of antibody and heat-labile factors. J. Lab. Clin. Med. 83: $73-78$.

55. Müller-Eberhard, H. J. 1975. Complement. Annu. Rev. Biochem. 44: 697-724.

56. Winkelstein, J. A., H. S. Shin, and W. B. Wood. 1972. Heat-labile opsonins to pneumococcus. III. The participation of immunoglobulin and of the alternate pathway of $\mathrm{C} 3$ activation. J. Immunol. 108: 1681-1689.

57. Polhill, R. B., K. M. Pruitt, and R. B. Johnson, 1976. Demonstration of a requirement for antibody in the alternative complement pathway (acp). Pediatr. Res. 10: 392A. (Abstr.)

58. Helgeland, S. M., and A Grov. 1971. Immunochemical characterization of staphylococcal and micrococcal mucopeptides. Acta Pathol. Microbiol. Scand. Sec. B Microbiol. 79: 819-826.

59. Morrison, D. C., and L. F. Kline. 1977. Activation of the classical and properdin pathways of complement by bacterial lipopolysaccharides (LPS). J. Immunol. 118: $362-368$.

60. Scribner, D. J., and D. Fahrney. 1976. Neutrophil receptors for IgG and complement: their role in the attachment and ingestion phases of phagocytosis. $J$. Immunol. 116: 892-897.

61. Verhoef, J., P. K. Peterson, and P. G. Quie. 1977. Human polymorphonuclear leukocyte receptors for staphylococcal opsonins. Immunology 33: 231-240.

62. Karakawa, W. W., D. G. Braun, H. Lackland, and R. M. Krause. 1968. Immunochemical studies on the crossreactivity between streptococcal and staphylococcal mucopeptide. J. Exp. Med. 128: 325-340.

63. Crowder, J. G., and A. White. 1972. Teichoic acid antibodies in staphylococcal and nonstaphylococcal endocarditis. Ann. Intern. Med. 77: 87-90. 